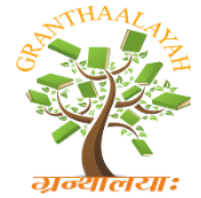

INTERNATIONAL JOURNAL OF RESEARCH GRANTHAALAYAH A knowledge Repository

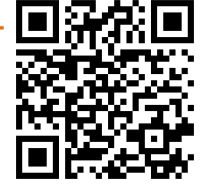

Management

\title{
ANALYSIS OF SENIOR HIGH SCHOOL -ACCOUNTANCY, BUSINESS AND MANAGEMENT STRAND TEACHERS PERFORMANCE
}

\author{
Roxer Erwin B. Garcia ${ }^{1}$, Jennielle Anne B. Narca ${ }^{2}$, John Alexis Narca ${ }^{3}$, Len Kristinne P. \\ Mariano ${ }^{4}$, Jennifer G. Fronda ${ }^{5}$ \\ ${ }^{1}$ DepEd-Schools Division of Nueva Ecija \\ 2 DepEd-Schools Division of Muñoz \\ ${ }^{3,4}$ Land Bank of the Philippines-Cabanatuan \\ ${ }^{5}$ Nueva Ecija University of Science and Technology

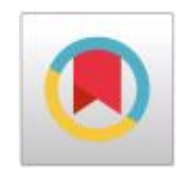

\begin{abstract}
This research aimed to assess the level of teaching standards competence of Senior High SchoolAccountancy, Business and Management (ABM) Teachers using the Classroom Observation Tool (COT) provided in the Philippine Professional Standards for Teachers - Results-based Performance Management System (PPST-RPMS). Likewise, to determine the relationship and significant difference in performance level when they were grouped according to age, sex, employment status, position, years of teaching experience, educational attainment, and grade level taught. The respondents represented the whole population of ABM teachers under Schools Division of Nueva Ecija (SDO-Nueva Ecija) which composed of 57 teachers holding Teacher IIII positions in 15 public schools offering ABM strand. Descriptive correlational research design was used, while the researchers utilized PPST-RPMS-standard COT to gather data. Descriptive analyses using the Mean, Percentage, Frequency count, Pearson Product Moment of Correlation, and ANOVA were utilized to analyse the gathered data. The study shows that mean years of teaching experience of the SHS-ABM public teachers were only 3 years, thus, the need to assess their performance. The findings revealed that the mean performance level of the respondents is Consolidating (expected attainment level for Teacher I-III positions) at 6.05. Moreover, the findings showed no significant difference in performance level when they were grouped according to age, sex, employment status, position, years of teaching experience, educational attainment, and grade level taught. Furthermore, overall findings revealed no significant relationship between the profile variables and the COT ratings of the respondents.
\end{abstract}

Keywords: Senior High School; Accountancy; Business and Management; Class Observation Tool; Philippine Professional Standards for Teachers; Teaching Performance.

Cite This Article: Roxer Erwin B. Garcia, Jennielle Anne B. Narca, John Alexis Narca, Len Kristinne P. Mariano, and Jennifer G. Fronda. (2020). "ANALYSIS OF SENIOR HIGH SCHOOL -ACCOUNTANCY, BUSINESS AND MANAGEMENT STRAND TEACHERS PERFORMANCE" International Journal of Research - Granthaalayah, 8(1), 131-137. https://doi.org/10.29121/granthaalayah.v8.i1.2020.260. 


\section{Introduction}

In Southeast Asia, Philippines is the last to join its neighbors in adopting an education system which provides more opportunities to students on a global scale through adding two more years in basic education.

This improved education system took effect when Philippine Congress approved Republic Act 10533 or the Enhanced Basic Education Act of 2013. It was then implemented by the Department of Education through DepEd Order 31 s. 2012 which has provided a 13-year basic education journey where students shall complete Kindergarten, Grades 1 to 6 (elementary grade), Grades 7 to 10 (junior grade) and Grades 11 to 12 (senior grade) before one can receive a high school diploma. Senior High School (SHS) is where students begin to study subjects that introduce them to their preferred career path.

$\mathrm{ABM}$ is one of the strands under Academic track of SHS K-12 Basic Education Curriculum offering for learners who preferred to continue college and pursue Accountancy or Business Courses and other related courses.

Most of the Accountancy, Business and Management-Senior High School (ABM-SHS) teachers started teaching on the first year of SHS implementation on June 2016. Teachers with less than 3 years of experience has an effect to the quality of teachers' instructional practice (Araujo et al, 2014) thus, assessing their performance is crucial to determine their level of competence in achieving the set competencies in $\mathrm{ABM}$ strand and quality of teaching to provide basis for appropriate interventions and formulation of development plans for teachers to attain the expected level for ABM teachers.

The Department of Education (DepEd) has established the Results-Based Performance Management System (RPMS) which is aligned with the Philippine Professional Standards for Teachers (PPST) as mechanism to systematically manage, measure and monitor teachers' performance. The PPST outlines the required competencies and skills of quality teachers. To develop and validate the RPMS-PPST tools which help in measuring and monitoring teachers' performance, the Philippine National Research Center for Teacher Quality (RCTQ), together with the Bureau of Human Resource and Organizational Development (BHROD), National Educators Academy of the Philippines (NEAP), Teacher's Education Council (TEC) and the Basic Education Sector Transformation (BEST) program were converged.

(deped.gov.ph/2018/10/03/ppst-aligned-rpms-a-guide-for-teachers-by-teachers).

The Classroom Observation Tool (COT) mandated in the PPST-RPMS provides evidence of actual teacher performance, their strengths and areas for development and the impact of their practice. The COT was made objective and standardized to be used for coaching, mentoring, review and evaluation of teachers' performance which provides results for their professional development. COT indicators were pre-determined and have been agreed upon by the observer/s and the teacher themselves to ensure their preparedness on what is expected and what to prepare during the observation schedule. (deped.gov.ph/2018/10/03/statement-on-the-demand-to-stop-all-on-goingclass-observations/). 


\section{Objectives of The Study}

The study intends to provide analysis of ABM-SHS teachers performance using the COT with regards to the seven (7) observable indicators for teachers of PPST-RPMS objectives. It also aims to provide reliable findings for basis of collective recommendations, appropriate interventions and to help address the possible gaps from their actual to expected performance level.

\section{Materials and Methods}

Descriptive research was used in this study to assess the teaching performance level of ABM-SHS teachers. Likewise, it was utilized to determine the significant difference in their teaching performance level while correlational research design was used to assess the relationship between profile variables and the COT ratings.

The respondents represented the whole population of the ABM-SHS teachers under the DepEdSchools Division of Nueva Ecija which composed of fifty-seven (57) teachers holding Teacher IIII positions in fifteen (15) public schools offering ABM strand. These teachers are being observed and rated for their actual classroom teaching performance by school Master Teacher/s or School Head.

The data were gathered using the standardized tool in the PPST-RPMS. Likewise, to measure the teaching standards and competence of teachers, the standardized instrument of PPST developed by the DepEd was used. Since the instrument used is standardized, reliability and validity were not conducted.

In data gathering, the researchers who are connected with DepEd, secured approval of the study to the Schools Division of Nueva Ecija and requested a copy of teachers COT ratings from the schools concerned. Teachers were assured of full confidentiality of the information.

Appropriate statistical tools were used to analyse the data gathered that is capable to do descriptive and inferential analyses. The mean was used to determine the demographic characteristics of ABM-SHS Teachers and their level of teaching standard competence. Meanwhile, the Pearson Product Moment of Correlation and ANNOVA were employed to determine significant relationship and significant difference between teachers' profile variables and teacher performance.

\section{Results and Discussion}

\section{Demographic Characteristics}

Table 1.A: Demographics

\begin{tabular}{|c|c|c|c|c|c|c|c|c|c|c|c|c|}
\hline \multirow[t]{2}{*}{ Particulars } & \multicolumn{8}{|c|}{ Age } & \multicolumn{2}{|c|}{ Gender } & \multicolumn{2}{|c|}{$\begin{array}{c}\text { Appointme } \\
\text { nt Status }\end{array}$} \\
\hline & 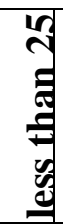 & $\begin{array}{l}\text { लి } \\
\text { in }\end{array}$ & $\frac{n}{\frac{1}{n}}$ & $\begin{array}{l}\text { Pi } \\
\text { do } \\
\text { లे }\end{array}$ & 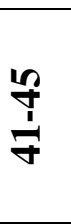 & $\begin{array}{l}\text { ஜे } \\
\dot{b} \\
\dot{\gamma}\end{array}$ & 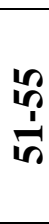 & 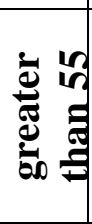 & $\frac{\frac{0}{\sigma}}{\sum}$ & 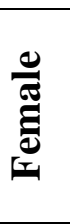 & 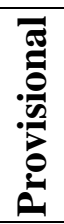 & 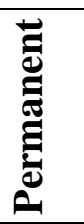 \\
\hline Frequency & 2 & 17 & 10 & 11 & 12 & 3 & 1 & 1 & 12 & 45 & 6 & 51 \\
\hline
\end{tabular}


DOI: 10.5281/zenodo.3631922

\begin{tabular}{|l|c|c|c|c|c|c|c|c|c|c|c|c|}
\hline Percentage & 3 & 29.8 & 17.5 & 19.3 & 21.1 & 5.3 & 1.8 & 1.8 & 21.1 & 78.9 & 10.5 & 89.5 \\
& 5 & $\%$ & $\%$ & $\%$ & $\%$ & $\%$ & $\%$ & $\%$ & $\%$ & $\%$ & $\%$ & $\%$ \\
& $\%$ & & & & & & & & & \\
& & & & & & & \\
& $57=100 \%$ & $57=100 \%$ & $57=100 \%$ \\
\hline
\end{tabular}

Table 1.B: Demographics

\begin{tabular}{|c|c|c|c|c|c|c|c|c|c|c|}
\hline \multicolumn{3}{|c|}{ Position } & \multicolumn{3}{|c|}{ Teaching Experience } & \multicolumn{2}{|c|}{ Grade Level } & \multicolumn{3}{|c|}{ Educational Attainment } \\
\hline 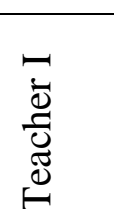 & 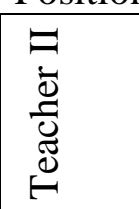 & 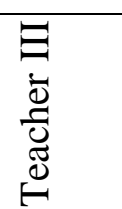 & 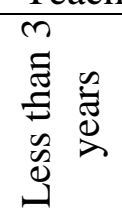 & 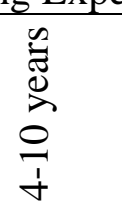 & 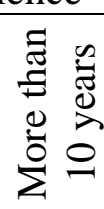 & $\begin{array}{l}\Xi \\
\tilde{\sigma} \\
\tilde{\sigma}\end{array}$ & 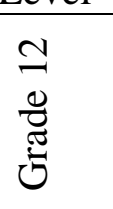 & 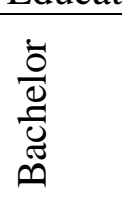 & 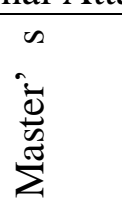 & 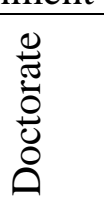 \\
\hline 2 & 26 & 29 & 46 & 7 & 4 & 30 & 27 & 33 & 22 & 2 \\
\hline $3.5 \%$ & $45.6 \%$ & $50.9 \%$ & $80.7 \%$ & $12.3 \%$ & $7.0 \%$ & $52.6 \%$ & $47.4 \%$ & $57.9 \%$ & $38.6 \%$ & $3.5 \%$ \\
\hline & $57=100$ & & & & & & & & $=100^{\circ}$ & \\
\hline
\end{tabular}

Based on the gathered data, majority of ABM-SHS teachers are having the age range of 25-30 years old, of which, $79.90 \%$ are female. Data shows that $89.5 \%$ are already having a permanent appointment status, and $50.90 \%$ of the respondents are holding the position of Teacher III. The respondents are composed of doctorate degree holders (3.5\%), master's degree holders (38.6\%) and bachelor's degree holders (57.9\%) who are teaching with almost the same number of students in Grades 11 and 12. It is notable that $80.7 \%$ or majority are having 3 years and below teaching experience. Hence, there is a need to evaluate their performance as bases for their personal growth and professional development plan.

\section{Teachers' Performance Rating}

Table 2.A: Abm-Shs Teachers Cot Rating

\begin{tabular}{|l|c|c|c|c|c|c|c|c|}
\hline \multicolumn{7}{|c|}{ INDICATORS } & Mean \\
\hline No. & 1 & 2 & 3 & 4 & 5 & 6 & 7 & \\
\hline Ave. Rating & 6.07 & 5.96 & 5.75 & 6.32 & 6.32 & 5.93 & 6.02 & 6.05 \\
\hline
\end{tabular}

Based on COT ratings, teaching performance of ABM-SHS public teachers of Schools Division of Nueva Ecija as a whole are within the expected attained level which is Consolidating ( $M=6.05)$. The total result is Proficient, four (4) indicators were rated within expected level, their knowledge application of content within curriculum ( $M=6.07)$, classroom structure management to engage learners in meaningful exploration, discovery and hands-on activities within the range of physical learning environment $(\mathrm{M}=6.32)$, constructive management of learning behaviour by applying positive discipline to ensure learning-focused environment $(\mathrm{M}=6.32)$ and developmental planning, management and implementation of sequences teaching and learning process to meet curriculum requirements and varied teaching contents $(\mathrm{M}=6.02)$, but it still implies the need for improvement on the three (3) indicators rated slightly below expected level which were their teaching strategies that enhance learners achievement in literacy and numeracy skills $(M=5.96)$, teaching strategies to develop critical and creative thinking as well as other higher-order thinking skills $(\mathrm{M}=5.75)$, and use of differentiated, developmentally appropriate learning experiences to address learners' gender, needs, strengths, interests and experience ( $M=5.93)$. 


\section{Difference and relationship of demographic variables and teacher performance}

Table 3.A: Relationship Between Profile Variables and Teachers Performance

\begin{tabular}{|l|c|c|c|}
\hline Profile & Pearson Correlation & Sig. (2-tailed) & Interpretation \\
\hline Actual Age & .049 & .720 & NS \\
\hline Gender & -0.70 & .607 & NS \\
\hline Appointment Status & -.108 & .423 & NS \\
\hline Position & .189 & .159 & NS \\
\hline Years in Service & .057 & .675 & NS \\
\hline Educational Attainment & .064 & .634 & NS \\
\hline Grade Level Thought & .023 & .864 & NS \\
\hline
\end{tabular}

Note: Correlation is significant at the 0.05 level (2-tailed), NS=not significant

Table 3.B: Difference Between Profile Variables and Teachers Performance

\begin{tabular}{|l|c|c|c|}
\hline Profile & F & Sig & Interpretation \\
\hline Age & .489 & .838 & NS \\
\hline Gender & .268 & .607 & NS \\
\hline Appointment & .653 & .423 & NS \\
\hline Position & 1.003 & .374 & NS \\
\hline Years in Service & .629 & .537 & NS \\
\hline Educational Attainment & .229 & .796 & NS \\
\hline Grade Level Thought & .029 & .864 & NS \\
\hline
\end{tabular}

Note: Difference is significant at the 0.05 level, $\mathrm{NS}=$ not significant

The result shows no significant difference and relationship in all demographic variables and teaching performance using the ANOVA as shown in Table III.A and the Pearson product moment of correlation (PPM) in Table III.B.

\section{Findings}

The findings show that most ABM-SHS public schools teachers in School Division of Nueva Ecija have mostly none to minimal teaching experience upon entering the profession, yet received Proficient rating or Career Stage 2 in PPST during the $1^{\text {st }}$ quarter of $3^{\text {rd }}$ year of SHS implementation which is the expected level for Teachers I-III. The indicators for classroom structure management and constructive management of learning behaviour got the highest rating, a manifestation that school's practice high regard for child-friendly and motivating learning environment by constructively applying positive discipline. On the other hand, the indicators for teaching strategies and use of differentiated, developmentally appropriate learning experiences received lowest ratings that reflect the previous findings that most ABM-SHS teachers were not teachers by profession and still learning teaching experience. Moreover, the study shows that age, gender, appointment status, position, length of service, educational attainment and grade level taught were seemingly not determinant and could not relate to the performance of the ABM-SHS teachers. 


\section{Conclusion}

The ABM-SHS public school teachers in Schools Division of Nueva Ecija were rated Proficient. Proficient teachers professionally and independently apply vital skills in teaching and learning process. However, their performance rating indicates that they need to improve and develop their teaching strategies. Their good performance will definitely result to quality learning and performance of students. Teaching performance is mostly affected by experience in the profession (Roberto \& Madrigal, 2019) but this study seemingly shows it has no evident relationship in length of experience and other demographics variables. This could be because ABM strand is new and teachers were all trained simultaneously in the start of implementation. Teachers' performance should be continuously monitored to help attain the strand desired objectives. Their Professional growth should be given importance like pursuing master's degree, attending trainings, regular coaching and mentoring to maintain proficient performance. Schools Division may opt to fund appropriation plans to provide trainings or other interventions for the continuous improvement of the teachers.

\section{Recommendation}

It is recommended that ABM-SHS teachers' personal developmental and improvement plans should focus on strengthening their use of teaching strategies that enhance learner's literacy and numeracy skills achievement, application range of teaching strategies to develop learners' critical and creative thinking and use of differentiated, developmentally appropriate learning experiences to address learners' gender, needs, strengths, interests and experience. School Heads have to stablish organized mentoring and coaching plans and motivate teacher to pursue masters degree. The Schools Division may consider appropriating funds for teachers' continuous development support like trainings and updates on teaching pedagogy. Continuous performance evaluation is also recommended for their professional development plans.

Future researchers are also encouraged to conduct related or same studies covering the whole cycle of the COT evaluation rating to supplement the results and findings.

\section{References}

[1] COT Ratings. Schools Division of Nueva Ecija., Sta. Rosa, Nueva Ecija

[2] Department of Education. (2012). Policy guidelines on the implementation of grades 11 to 10 of the $\mathrm{K}$ to 12 basic education curriculum (BEC) effective school year 2012-2013. Retrieved from http://www.deped.gov.ph/orders/do-31-s-2012

[3] Department of Education. (2017). National adoptation and implementation of the Philippine professional standards for teachers. Retrieved from http://www.deped.gov.ph/orders/do-42-s-2017

[4] Department of Education (2018) Results-based performance management system manual for teachers and school heads.

[5] Department of Education. (2019) Policy guidelines on the $\mathrm{K}$ to 12 basic education programs. Retrieved from https://www.deped.gov.ph>2019/08/22>august-22-2019-do-021-s-2019

[6] Department of Education. (n.d.). Statement on the demand to stop all on-going class observation. Retrieved from https://www.deped.gov.ph/2018/10/03/statement-on-the-demand-to-stop-all-ongoing-class-observations/ 
[7] Department of Education. PPST-aligned RPMS: A guide for teachers by teachers. Retrieved from https://www.deped.gov.ph/2018/10/03/ppst-aligned-rpms-a-guide-for-teachers-by-teachers/

[8] Education for All 2015 National Review Report: Philippines (2014). Retrieved from http://unesdoc.unesco.org/image/0023/002303/230331e.pdf

[9] M.C. Araujo, P. Carneiro, Y. Cruz-Aguayo, \& N. Shady (2014). A Helping Hand? Teacher Quality and Learning Outcomes in Kindergarten. 34 (2) 1415-1453-2016

[10] Philippine Professional Standards for Teachers. (2017). Department of Education-Teacher Education Council. Republic of the Philippines.

[11] Tucson (2015). Framework for 21st Century Learning. (2015). Retrieved from www.p21.org

[12] Paper commissioned for the Global Education Monitoring Report 2016, Education for people and planet: Creating sustainable futures for all. Measures of quality through classroom observation for the sustainable development goals: Lesson from low-and-middle-income countries. Retrieved from https://unesdoc.unesco.org/ark:/48223/pf0000245841

[13] RA 10533 (2013) Enhanced Basic Education Act

[14] Roberto, J. \& Madriaga, D.V. (2019). Teacher Quality in the Light of the Philippine Professional Standards for Teachers. Retrieved from https://www.researchgate.net/publication/332103677

\footnotetext{
*Corresponding author.

E-mail address: roxererwin.garcia@ deped.gov.ph/jennielleanne.narca@ deped.gov.ph/

alexisnarca2292@gmail.com/lenkristinne25@gmail.com
} 